\title{
In this issue...
}

Money, money, money. Politics' link to, and even dependence on economic interests did not require Marx to discover. Neither did it require Marx's critics to recognize that the relationship was neither deterministic nor simple. The political economy of international politics, indeed, is a discipline that pre-dates the emergence of contemporary political science and international relations.

In the United States, political corruption investigators follow the money trail, political consultants abide by "it's the economy, stupid" electoral mantra, Alan Greenspan's respiratory rate affects far more than presidential pronouncements, and billionaires à la Bill Gates and Ted Turner assume iconic stature as monopolists or saviors of American innovation and the United Nations. Internationally, the World Bank and the International Monetary Fund, in concert with giant private financial institutions exert decisive influence in some countries and regions. Growing concern about the "globalized" financial and economic control effected by mega-corporations via the World Trade Organization, for example, led to increasing resistance in 1999 and 2000. In short, the tie between politics and money, economics and finance cannot be missed.

Yet, the instrumentality of economic means for political power should never be forgotten - and is not by our authors. Decisive and motivated, political leadership can marshal financial resources and economic strengths for goals of their clique, movement, party or country. Richard Rosecrance's seminal The Rise of the Trading State in 1986 is, perhaps, the most frequent jumping-off point for such arguments. Conversely, trade dependence and vulnerability to economic sanctions have received ample scholarly attention.

In Volume 37, Number 3 (September 2000), International Politics gives the floor to three perceptive scholars whose takes on money and power - in varied contexts - provide significant new insights into the role of money, market and finance on diplomacy, democracy and the state. Their findings and arguments are powerful correctives to conventional wisdom about such relationships.

Randall E. Newnham (Pennsylvania State University, Berks-Lehigh Valley College) probes the efforts by three wealthy states, the identities of which were (and are) troubled by a separation of one nation into two political entities, to "buy" diplomatic recognition. Newnham's focus is very precise...on West German, Taiwanese and South Korean attempts to use their considerable economic clout as leverage in diplomatic recognition competition with their ideologically opposite neighboring regime. Such a study, however, offers weighty contributions to our understanding of much wider, theoretically important issues - the fungibility of economic means for political purposes, and the changing nature of sovereignty. Newnham finds incontrovertible evidence that diplomatic recognition has been affected or produced by economic inducements. From this, one might infer that a critical component of sovereignty is "for sale" - or at least not immune from being bought - and that money really does talk in diplomatic circles. 
But, when it comes to a regime's democratic credentials, it appears that financial inducements have had little or no effect on Beijing. William H. Thornton (National Cheng Kung University) argues evocatively that the communist party government of China has utilized its expanding economic capacity - and a very high growth rate since the late $1980 \mathrm{~s}$ - as leverage against democratic reform. The "democratic teleology" holds that the market, and international engagement with it, will ipso facto generate democratic behavior. Ownership, profit and other tenets of a market economy in China, as long as US and Western constructive engagement continue, are presumed to predict greater respect for human rights, broadened powers for non-Communist Party institutions, etc. But, Thornton says, all of this is the product of "fortune-tellers" - i.e., star-gazing and wishful thinking - disconnected from Chinese reality. Economic growth and foreign engagement in the Chinese market have not spurred democracy, says Thornton. Instead, democratic teleology makes us believers in something that does not exist. Rather than expanding democracy, we thicken the wallets of Communist Party officials while providing more secure finances with which to enhance the nuclear and conventional capabilities of the Peoples Liberation Army.

Such a hard-hitting and not-very-reassuring portrait of China is followed by a constructivist reassessment of the state-global economy relationship by Mary Geske (Smith College). Globalization, a theme explored in depth by International Politics in Volume 36, Number 3 (September 1999) via articles by James Rosenau, Fred Dallmayr, and Allaine Cerwonka, is never far away from any discussion about international politics at the turn of the century. Geske's laboratory is US foreign economic policy in the context of two episodes that rocked the international financial community in the latter twentieth century - the Brazilian debt crisis which (more or less) began in 1982 and the collapse of the Mexican peso in 1994. In both instances, the US intervened massively and quickly. The American role, and the volume, speed, and independence of international financial transactions and instruments are relatively new, and lead Geske to ask whether global market forces determine a state's (i.e., the US) foreign economic interests or vice versa? Seeking an answer, Geske considers the analytical contributions of dominant schools of thought - neoliberal institutionalism and realism. These she finds wanting, and turns to the insights of constructivist theory for a more holistic account of the state-global economy relationship. From the constructivist standpoint, Geske comments on the practices, beliefs and ideas that affect US interests and policies - the subjective origins of US policy preferences.

Together, Newnham, Thornton and Geske send stark messages to those whom might think that we already understand the link between money and diplomacy, market economics and democratic governance, global finance and national policy. These essays argue forcefully that we have a lot to learn, and offer building blocks from which new and better explanations can be developed. If sovereignty can be bought, if economic growth from market reforms can strengthen authoritarian systems that trample human rights, and if states' foreign economic policies are guided less by "interests" than perception, then we need to recalibrate how we see fundamental concepts of international politics. At International Politics, we have followed 
the increasing questions about the effects of a globalized market on sovereignty (e.g., Peter Dombrowski and Richard Mansbach, Volume 36, Number 1, March 1999, "From Sovereign States to Sovereign Markets"), and our continuing interest is more than warranted.

Two articles in Volume 37, Number 3 lead to intriguing and vital questions, albeit of quite different kinds. Stephen White, Sarah Oates, Clelia Rontonyanni and Bill Miller (University of Glasgow) have based their article on 1998 national public opinion research in post-communist Europe, using questionnaire items focused on attitudes towards the European Union and NATO in four countries - the Czech Republic, Slovakia, Ukraine and Bulgaria. Attitudes associated with support for joining either the EU or NATO suggest a great deal about the strengths and weaknesses of "western enlargement," and enable the authors to identify traits of those most likely and least likely to be enthusiastic about their country's membership. Their evidence is compelling that NATO's extension east is viewed, in these countries at least, with far less enthusiasm than EU membership. Given attention that International Politics has devoted to NATO enlargement in prior volumes, the White, et. al. article is an essential coda. Readers should compare the weak enthusiasm for NATO enlargement to the realist arguments of Stephen Blank favoring enlargement (Volume 36, Number 1, March 1999, "NATO Enlargement Between Rhetoric and Realism"), the critique of the Alliance's expansion presented by Sean Kay (Volume 35, Number 4, December 1998, "Deconstructing an Alliance"), and the details of the Clinton Administration's agenda and decision-making provided by Roberto Menotti (Volume 36, Number 2, June 1999, "US Policy and NATO Enlargement: Clinton's 'Unspoken Agenda"').

An intriguing question also motivates Robert E. Harkavy (Pennsylvania State University). When defeated (especially in a military sense), does the resulting injury to selfimage and humiliation lead, inexorably, through rage to a perilous quest for revenge and retribution? In his quest for insight into such a question, Harkavy mines a very wide range of literatures and offers to the reader an intellectual excursion of extraordinary scope. Rather than an empirical test of an existing hypothesis, Harkavy's essay develops the intellectual bases for a hypothesis of considerable importance for theory and policy. Defeat that leaves some room for residual honor may, if Harkavy's notions are correct, be a surer way to avoid future recurrence of conflict than seeking no-compromise triumph. But, such policy implications are only a small part of what his essay may mean. By assembling learning from many disciplines, Harkavy points to a deeper and more lasting understanding of how wars lead to future wars, how some conflicts seem perpetual, and the $21^{\text {st }}$ Century seems to have begun much like the last one with no apparent "progress" of humankind in war-avoidance.

With the further development of our Book Review section, this issue offers review essays by Ted Hopf and Elizabeth R. DeSombre, as well as an array of shorter reviews. Hopf looks at recent works that apply and develop constructivist theory, from which he sees arising the demand that the field reconnect international, domestic and local, thereby enlarging our understanding of each. DeSombre, an author featured in Volume 37, Number 2 ("Flags of Convenience..."), continues her welcome association with International Politics through an essay that considers prominent works on international environmental law. For DeSombre, the books she assesses 
succeed in turning an important corner - rather than revisiting the perennial "do institutions matter?" question, these examples of recent literature tackle conditions and processes that enable international accords to implement their intended goals.

For our readers, this is a "full" issue - filled with challenging ideas, important empirical research and timely evaluations of new theoretically relevant literature. Issues in the near future will continue our effort to serve as an outlet for important new thinking on transnational issues and global problems - with work on the meaning of sovereign authority, citizenship, private armies, Russia's regional and global role, NGOs and international law, and much more. Stay tuned.

The Editors 